\title{
,ane \\ Alphacoronaviruses Are Common in Bats in the Upper Midwestern United States
}

\author{
Reagan Schaeffer, Gun Temeeyasen and Ben M. Hause *(D)
}

Citation: Schaeffer, R.; Temeeyasen, G.; Hause, B.M. Alphacoronaviruses Are Common in Bats in the Upper Midwestern United States. Viruses 2022, 14, 184. https://doi.org/ $10.3390 / \mathrm{v} 14020184$

Academic Editors:

Luis Martinez-Sobrido and

Fernando Almazan Toral

Received: 28 December 2021

Accepted: 17 January 2022

Published: 19 January 2022

Publisher's Note: MDPI stays neutral with regard to jurisdictional claims in published maps and institutional affiliations.

Copyright: (C) 2022 by the authors. Licensee MDPI, Basel, Switzerland. This article is an open access article distributed under the terms and conditions of the Creative Commons Attribution (CC BY) license (https:// creativecommons.org/licenses/by/ $4.0 /)$.
Department of Veterinary and Biomedical Sciences, South Dakota State University, Brookings, SD 57007, USA; reagan.schaeffer@jacks.sdstate.edu (R.S.); gun.temeeyasen@sdstate.edu (G.T.)

* Correspondence: Benjamin.Hause@sdstate.edu

\begin{abstract}
Bats are a reservoir for coronaviruses (CoVs) that periodically spill over to humans, as evidenced by severe acute respiratory syndrome coronavirus (SARS-CoV) and SARS-CoV-2. A collection of 174 bat samples originating from South Dakota, Minnesota, Iowa, and Nebraska submitted for rabies virus testing due to human exposure were analyzed using a pan-coronavirus PCR. A previously partially characterized $\mathrm{CoV}$, Eptesicus bat $\mathrm{CoV}$, was identified in 12 (6.9\%) samples by nested RT-PCR. Six near-complete genomes were determined. Genetic analysis found a high similarity between all CoV-positive samples, Rocky Mountain bat CoV 65 and alphacoronavirus HCQD-2020 recently identified in South Korea. Phylogenetic analysis of genome sequences showed EbCoV is closely related to bat CoV HKU2 and swine acute diarrhea syndrome CoV; however, topological incongruences were noted for the spike gene that was more closely related to porcine epidemic diarrhea virus. Similar to some alphaCoVs, a novel gene, ORF7, was discovered downstream of the nucleocapsid, whose protein lacked similarity to known proteins. The widespread circulation of $\mathrm{EbCoV}$ with similarities to bat viruses that have spilled over to swine warrants further surveillance.
\end{abstract}

Keywords: Alphacoronavirus; coronavirus; Eptesicus; bats; zoonotic

\section{Introduction}

Coronaviruses (CoVs) are enveloped, positive-sense RNA viruses in the family Coronaviridae, of the order Nidovirales [1]. CoVs belong to the realm Riboviria, a taxon of viruses that use RNA-dependent RNA-polymerases (RdRps) for reverse transcription of the viral genome, which replicates in the cytoplasm of the host cell [1]. CoVs comprise four genera from the Coronavirinae subfamily: Alphacoronavirus, Betacoronavirus, Gammacoronavirus, and Deltacoronavirus [1]. Alphacoronaviruses (alphaCoVs) and betacoronaviruses (betaCoVs) infect a variety of mammalian species, including humans, cows, swine, rodents, cats, dogs, and bats, while deltacoronaviruses and gammacoronaviruses principally infect avian species [2-4].

Coronaviruses are the largest known positive-sense RNA viruses, with genome sizes of approximately 27-33 kilobases [3]. The approximate $5^{\prime}$-two thirds of the genome encode a large polyprotein that is post-translationally cleaved into a variety of non-structural proteins necessary for viral replication and antagonism of the host immune response. A propensity for recombination allows for rapid virus mutation and host switching. The spike (S) glycoprotein projects from the virion surface and mediates viral entry into host cells $[5,6]$. Consequently, the $S$ protein is a critical determinant of viral host range and tissue tropism [6]. The remaining structural proteins include the membrane (M), nucleocapsid (N), and envelope (E) proteins. Accessory genes are also variably encoded in the CoV genome.

Prior to the discovery of severe acute respiratory syndrome coronavirus (SARS-CoV) in 2003, CoVs were not considered highly pathogenic in humans, with infection typically resulting in mild respiratory disease $[7,8]$. In contrast, the past 20 years have seen three worldwide pandemics caused by suspected bat-origin CoVs with devastating effects on 
human health. To date, seven CoVs are known to cause acute respiratory tract infections in humans $[7,9,10]$. Besides SARS-CoV and SARS-CoV-2, five other human pathogenic CoVs have been identified. Human CoV-229E (HCoV-229E) and human CoV-OC43 (HCoV-OC43) were discovered in the 1960s $[7,11]$. Human CoV-NL63 (HCoV-NL63) and human CoVHKU1 (HCoV-HKU1) were discovered in 2004 and 2005, respectively [8]. In November 2012, Middle East Respiratory Syndrome coronavirus (MERS-CoV) was identified [12]. While four of the known coronaviruses infecting humans, HCoV-229E, HCoV-OC43, HCoV-NL63, and HCoV-HKU1, cause mild respiratory symptoms, the deadly outbreaks of MERS-CoV, SARS-CoV, and SARS-CoV-2 demonstrate the need for coronavirus surveillance [11].

Several human CoVs share ancestry with bat CoVs, with spillover from closely related bat $\mathrm{CoVs}$ suspected for some human CoVs such as SARS-CoV [13]. It is thought that SARS-CoV-2 also originated bats, although more research is needed to verify this [14]. In addition, previous research has shown that bats are reservoirs for diverse alphaCoVs and betaCoVs [4].

Compared to elsewhere in the world, comparably little surveillance for bat CoVs have been performed in the United States. A pan-coronavirus PCR-based study of seven bat species collected from four sites in the Rocky Mountain region identified three distinct clusters of alpha-CoVs based on sequencing of a $440 \mathrm{nt}$ region of the RdRp domain [15]. One of these CoVs, Rocky Mountain bat CoV 65, was identified from Eptesicus fuscus, while the remaining CoV-positive bats belonged to the genera Myotis. Similarly, metagenomic analysis of E. fuscus, M. lucifugus, and Perimyotis subflavus bats from the Eastern U.S. identified alphaCoV sequences originating from at least three viruses [16]. More broadly, a review of bat CoVs detected in the Americas found that $89.4 \%$ of the $151 \mathrm{CoVs}$ described belonging to Alphacoronavirus, with the remainder in Betacoronavirus [17].

Here, to identify potentially novel bat CoVs that may pose a risk to humans, we screened bats submitted for rabies testing due to human exposure using a pan-coronavirus PCR. Six complete and six partial genomes were assembled that were highly similar to the partial genome of Rocky Mountain bat coronavirus 65. Phylogenetic analyses revealed evolutionary relationships to bat, livestock, and companion animal CoVs.

\section{Materials and Methods}

\subsection{Ethics Statement}

Bat samples were submitted to the South Dakota State University Animal Disease Research and Diagnostic Laboratory (SDSU ADRDL) for rabies testing due to human exposure, and as such, no specific approval was required. All tissue processing, RNA extraction, and viral isolation of the bat samples were performed in the SDSU ADRDL BSL-3 laboratory.

\subsection{Sample Collection and Processing}

Big brown bats (Eptesicus fuscus) submitted to SDSU ADRDL for rabies testing from March 2020 to July 2021 were used in this study. All 174 bat samples tested negative for rabies virus by fluorescent antibody detection. The bats originated from South Dakota, Minnesota, Iowa, and Nebraska. Tissue homogenates were assembled from pooled viscera in phosphate-buffered saline and clarified by centrifugation at $14,000 \times g$ for five minutes.

\subsection{RNA Extractions}

RNA was extracted from the bat homogenates using a Kingfisher sample purification system combined with MagMAX viral RNA extraction reagents.

\subsection{Nested Pan-CoV PCR}

A nested pan-CoV PCR was performed to detect CoV-positive samples. The outer PCR targeting the RdRp domain was adapted from a previously described assay [18]. An amount of $2 \mu \mathrm{L}$ extracted RNA, $5 \mu \mathrm{L}$ QIAGEN One Step RT-PCR 5X Buffer, $1 \mu \mathrm{L}$ dNTPs (QIAGEN, $10 \mathrm{mM}$ each), $1 \mu \mathrm{L}$ enzyme (QIAGEN), $2.5 \mu \mathrm{L} 10 \mu \mathrm{M}$ panCoV-F2 
(5'-AARTTYTAYGGHGGYTGG-3'), $2.5 \mu \mathrm{L} 10 \mu \mathrm{M}$ panCoV-R1 (5'-GARCARAATTCATGHGGDCC-3'), $0.25 \mu \mathrm{L} 40 \mathrm{U} / \mu \mathrm{L}$ RNaseOut (Invitrogen), and enough water to achieve a total of $25 \mu \mathrm{L}$ were combined. Using the Applied Biosystems 2720 Thermal Cycler, reverse transcription and initial denaturation were performed for $30 \mathrm{~min}$ at $50{ }^{\circ} \mathrm{C}$ and $15 \mathrm{~min}$ at $95^{\circ} \mathrm{C}$, followed by 35 cycles of $40 \mathrm{~s}$ at $94{ }^{\circ} \mathrm{C}, 40 \mathrm{~s}$ at $52^{\circ} \mathrm{C}$, and $1 \mathrm{~min}$ at $72{ }^{\circ} \mathrm{C}$, with a final extension for $10 \mathrm{~min}$ at $72{ }^{\circ} \mathrm{C}$, and a holding temperature of $4{ }^{\circ} \mathrm{C}$. The products were visualized on a $1.5 \%$ agarose gel, with an expected band size of $\sim 600 \mathrm{bp}$.

The nested PCR was adapted from a previously developed assay [19]. The outer PCR product was diluted at 1:10. One microliter of the diluted outer PCR product was added to a Master Mix containing $0.25 \mu \mathrm{L}$ TaKaRa rTaq ( $5 \mathrm{U} / \mu \mathrm{L}), 5 \mu \mathrm{L}$ 10X PCR buffer (TaKaRa), $4 \mu \mathrm{L}$ dNTPs (2.5 mM each), $2 \mu \mathrm{L} 10 \mu \mathrm{M}$ Pan_CoV_F-3 (5'-GAYTAYCCHAARTGTGAYMGH$\left.3^{\prime}\right), 2 \mu \mathrm{L} 10 \mu \mathrm{M}$ Pan_CoV_R-1 (5'-CCRTCATCAGAHARWATCAT-3'), and water to bring the amount to $50 \mu \mathrm{L}$. Thermal cycling was performed using the Applied Biosystems 2720 Thermal Cycler with 40 cycles of $30 \mathrm{~s}$ at $94{ }^{\circ} \mathrm{C}, 30 \mathrm{~s}$ at $48^{\circ} \mathrm{C}$, and $1 \mathrm{~min}$ at $72{ }^{\circ} \mathrm{C}$, with a hold of $4{ }^{\circ} \mathrm{C}$. The products were visualized on a $1.5 \%$ agarose gel, with an expected band size of $\sim 430 \mathrm{bp}$.

The detection breadth of the nested PCR assay was assessed using $15 \mathrm{CoV}$ references derived from cell culture. Reference viruses included porcine epidemic diarrhea virus (PEDV), five strains of bovine coronavirus (BCV), porcine deltacoronavirus (PDCoV), canine respiratory coronavirus $(\mathrm{CRCoV}), \mathrm{HuCoV}-\mathrm{OC} 43$, three strains of canine coronavirus $(\mathrm{CCoV})$, two strains of feline coronavirus $(\mathrm{FCoV})$, and equine coronavirus.

\subsection{Sanger Sequencing}

Nested PCR amplicons were purified with the NEB Monarch PCR and DNA Cleanup Kit, following manufacturer instructions for DNA cleanup and concentration. The concentration of the purified $\mathrm{CoV}$ samples was measured with the Invitrogen Qubit dsDNA High Sensitivity (HS) Assay Kit. Samples were diluted to a concentration of $4 \mathrm{ng} / \mu \mathrm{L}$ and submitted to the SDSU ADRDL for Sanger sequencing of the RdRp gene to confirm CoV PCR results.

\subsection{Metagenomic Sequencing}

Following the digestion of unprotected nucleic acids by a cocktail of DNases and RNases, RNA was extracted from the CoV-positive homogenates using the QIAamp viral RNA kit (Qiagen, Hilden, Germany). For samples that yielded incomplete genome sequences after the initial sequencing attempt, nuclease digested RNA was further purified using oligo-dT beads to enrich for polyadenylated RNA before continuing with sample preparation. Reverse transcription and second-strand synthesis were carried out using the SuperScript III First-Strand Synthesis System (Invitrogen) and Sequenase 2.0 DNA Polymerase (Applied Biosystems) using barcoded random hexamers FR26RV-N [20]. Complementary DNAs (cDNA) were then amplified by using TaKaRa rTaq with barcode primers FR20RV [20]. One ng of the resulting amplicons from each sample was used for library preparation. A Nextera XT library preparation kit was used to construct sequencing libraries, which were sequenced with an Illumina MiSeq machine. Using QIAGEN CLC Genomics, contigs were assembled de novo. Contigs were identified by BLASTX using the cloudblast feature implemented in Omicsbox.

\subsection{Phylogenetic Analysis}

Phylogenetic analysis was performed for genome sequences and for each gene individually, including species in the genera Alphacoronavirus, with SARS-CoV-2 included as an outgroup representing Betacoronavirus. Nucleotide sequences were aligned in MEGAX using ClustalW [21,22]. Phylogeny was inferred using the Maximum Likelihood method using the GTR+G model in MEGAX [21,22]. Tree topologies were assessed with 500 bootstrap replicates for genome and ORF1ab sequences, with 1000 bootstrap replicates utilized for remaining genes. 


\subsection{Recombination Analysis}

Recombination analysis was performed on the full genome using SimPlot [23]. This was verified using RDP4 [24]. The window size was set at 400 and the step size at 200 for both analyses. Recombination analysis was performed for $\mathrm{EbCoV}$ and reference sequences for PEDV, HCoV-NL63, HCoV-229E, bat CoV strain HKU2, Bat CoV strain 1A, CCoV, feline infectious peritonitis virus (FIPV), and transmissible gastroenteritis virus (TGEV).

\subsection{Viral Isolation}

Viral isolation was attempted for positive CoV samples on Vero76 and immortalized Eptesicus fuscus kidney (Efk3) cells. Cells were grown at $37{ }^{\circ} \mathrm{C}$ with $5 \% \mathrm{CO}_{2}$ in warmed DMEM media with $10 \%$ fetal bovine serum and $1 \%$ antibiotics and antimycotic (Gibco). Confluent monolayers in 12-well plates were inoculated with $100 \mu \mathrm{L}$ of unfiltered tissue homogenate and $100 \mu \mathrm{L} 0.22 \mu \mathrm{M}$ filtered homogenate, respectively. Virus isolation was attempted using both growth media as well as DMEM containing trypsin. The cells were incubated for seven days and then passed to new confluent monolayers. After seven days, $140 \mu \mathrm{L}$ of the cell culture was tested using the outer PCR method described in Section 2.4 after extracting RNA with the QIAamp viral RNA kit (Qiagen, Hilden, Germany). All cell cultures, filtered and unfiltered, were considered negative when no cytopathic effects were visible, and the outer PCR was negative according to gel electrophoresis.

\subsection{Accession Numbers}

The six complete bat CoV genomes were deposited into GenBank, according to the following accession numbers OL410607-OL410610, OL415261, and OL415262.

\section{Results}

\subsection{The Pan-Coronavirus PCR Detected All 15 Reference Coronaviruses}

The nested PCR sensitivity was tested with 15 known CoV references. All 15 viruses gave a single, intense band of the proper size for both outer and nested PCR reactions (Figure 1).
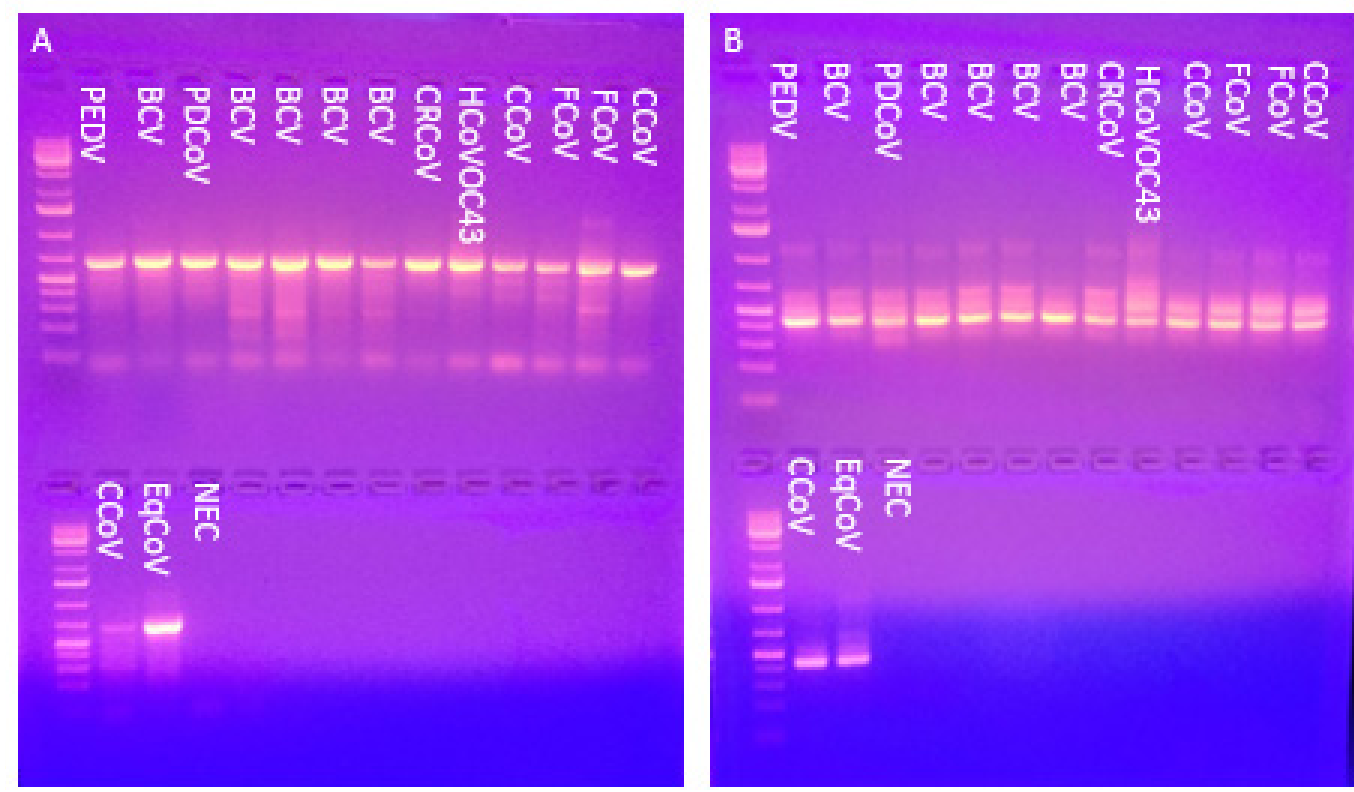

Figure 1. (A) Outer PCR for CoV references yielded a band $\sim 600 \mathrm{bp}$. (B) Nested PCR for CoV references yielded a band $\sim 430 \mathrm{bp}$. CoV references include porcine epidemic diarrhea virus (PEDV), five strains of bovine coronavirus $(\mathrm{BCV})$, porcine deltacoronavirus (PDCoV), canine respiratory coronavirus (CRCoV), human coronavirus OC-43 (HuCoV-OC43), three strains of canine coronavirus $(\mathrm{CCoV})$, two strains of feline coronavirus $(\mathrm{FCoV})$, and equine coronavirus. NEC, negative extraction control. 


\subsection{Novel Alphacoronavirus Discovered in Bats from South Dakota and Minnesota}

Of 174 bat specimens, 12 homogenates $(6.9 \%)$ were positive for CoV by nested PCR. The geographical distribution of samples and CoV-positives are shown in Table 1 and Supplementary Figure S1. A majority of both samples and CoV-positive samples originated in Minnehaha county, which is the most populous county in South Dakota (SD). Positive samples were approximately evenly distributed between urban (Minnehaha county; 7 out of $112(6.3 \%)$ ) and rural (all other counties; 5 out of $62(8.1 \%)$ ) sample sources. More samples were tested from the Eastern half of SD than the Western half.

Table 1. Distribution of bat samples tested and pan-coronavirus positive samples.

\begin{tabular}{ccc}
\hline County and State & Samples & Positive \\
\hline Minnehaha, SD & 112 & 7 \\
Yankton, SD & 6 & 1 \\
Charles Mix, SD & 4 & 1 \\
Turner, SD & 3 & \\
Clay, SD & 1 & \\
Brule, SD & 1 & \\
McCook, SD & 1 & \\
Lake, SD & 5 & \\
Hanson, SD & 1 & \\
Grant, SD & 1 & \\
Brookings, SD & 5 & \\
Codington, SD & 3 & \\
Spink, SD & 1 & \\
Davison, SD & 1 & \\
Hutchinson, SD & 4 & \\
Marshall, SD & 1 & \\
Hughes, SD & 1 & \\
Beadle, SD & 1 & \\
Custer, SD & 2 & \\
Pennington, SD & 2 & \\
Hamlin, SD & 1 & \\
Tripp, SD & 1 & \\
Deuel, SD & 1 & \\
Sanborn, SD & 1 & \\
Hanson, MN & 1 & \\
Lac qui Parle, MN & 1 & \\
Lyon, MN & 1 & \\
Rock, MN & 1 & \\
Redwood, MN & 1 & \\
Pipestone, MN & 1 & \\
Sioux, IA & & \\
Lyon, IA & 1 & \\
Boyd, NE & 1 & \\
\hline
\end{tabular}

Complete or near-complete coding regions of six genomes were assembled de novo. For the remaining positive samples, only partial RdRp domain sequences were determined. Genome completeness was assessed by open reading frame (ORF) and BLASTP analysis. The assembled genomes were 27,994 to 28,546 nucleotides in length and contained incomplete noncoding regions.

Sanger sequencing was performed on the nested PCR product for all 12 bat $\mathrm{CoV}$ positives. The Sanger sequences of the 12 positive bat $\mathrm{CoV}$ RdRp regions were analyzed by BLASTN, which found that the sequences were $96.0-98.2 \%$ similar to partial alphacoronavirus sequences determined from Eptesicus fuscus (Accession number JX537914.1). The previously determined partial E. fuscus $\mathrm{CoV}$ sequences were the basis for the inclusion of Eptesicus bat coronavirus (EbCoV) as a possible but not approved species in the genus $\mathrm{Al}$ phacoronavirus (https: / /ictv.global/taxonomy; accessed on 18 January 2022). Given the high 
similarity of our sequences to $\mathrm{EbCoV}$, the six complete and six RdRp sequences determined here likely belong to the proposed species $\mathrm{EbCoV}$.

\subsection{Genome Features of Eptesicus Bat Coronavirus}

The six EbCoV genomes shared 98-99\% nucleotide identity with each other. Open reading frame and BLASTP analysis identified genes that encode the replicase polyproteins ORF1ab, S glycoprotein, envelope (E) protein, membrane (M) protein, and nucleocapsid (N) protein (Figure 2). A putative accessory gene ORF3 was located between $\mathrm{S}$ and E. Another putative accessory gene, ORF7, was located downstream of the $\mathrm{N}$ gene. All EbCoV proteins were most similar to alphacoronavirus HCQD-2020 (HCQD-2020) recently reported from South Korea [25]. Greater than 97\% identity was found between EbCoV and HCQD-2020 for all proteins except S, where only $83.6 \%$ identity was found. The genes for S, ORF3, and E overlapped ORF1ab, S, and ORF3, respectively, by four, four, and 29 nucleotides (Table 2).

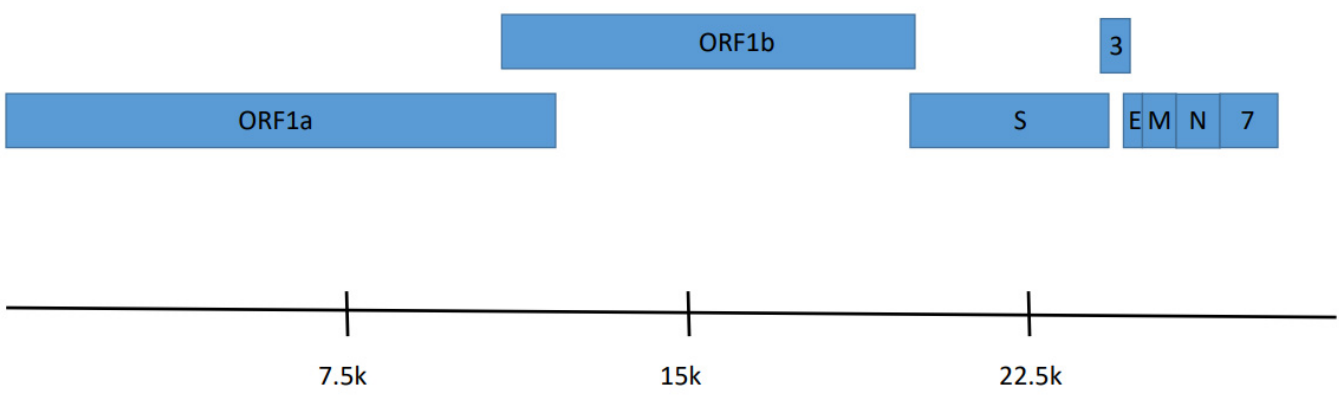

Figure 2. Genome organization of Eptesicus bat coronavirus. Genes for ORF1ab, Spike (S), ORF3 (3), Envelope (E), Membrane (M), Nucleocapsid (N), and ORF7 (7) are denoted.

Table 2. Genome organization of Eptesicus bat CoV strains determined from E. fuscus. Nucleotides for genes are shown. Predicted protein lengths are shown in parentheses. Incomplete sequences are indicated by *

\begin{tabular}{|c|c|c|c|c|c|c|c|}
\hline EbCoV Strain & ORF1ab & $S$ & ORF3 & $\mathrm{E}$ & $\mathbf{M}$ & $\mathbf{N}$ & ORF7 \\
\hline 15,712 & $\begin{array}{c}252-20,845 \\
(6864)\end{array}$ & $\begin{array}{c}20,842-24,873 \\
(1343)\end{array}$ & $\begin{array}{c}24,870-25,544 \\
(224)\end{array}$ & $\begin{array}{c}25,516-25,761 \\
(81)\end{array}$ & $\begin{array}{c}25,772-26,449 \\
(225)\end{array}$ & $\begin{array}{c}26,467-27,627 \\
(386)\end{array}$ & $\begin{array}{c}27,630-28,466 \\
\text { (278) }\end{array}$ \\
\hline 16,842 & $\begin{array}{c}357-20,356 \\
(6666) *\end{array}$ & $\begin{array}{c}20,353-24,384 \\
(1343)\end{array}$ & $\begin{array}{c}24,381-25,055 \\
(224)\end{array}$ & $\begin{array}{c}25,027-25,272 \\
(81)\end{array}$ & $\begin{array}{c}25,283-25,960 \\
(225)\end{array}$ & $\begin{array}{c}25,978-27,138 \\
(386)\end{array}$ & $\begin{array}{c}27,141-27,977 \\
(278)\end{array}$ \\
\hline 16,964 & $\begin{array}{c}97-20,690 \\
(6864)\end{array}$ & $\begin{array}{c}20,687-24,730 \\
(1347)\end{array}$ & $\begin{array}{c}24,727-25,401 \\
(224)\end{array}$ & $\begin{array}{c}25,373-25,618 \\
(81)\end{array}$ & $\begin{array}{c}25,629-26,306 \\
(225)\end{array}$ & $\begin{array}{c}26,324-27,484 \\
(386)\end{array}$ & $\begin{array}{c}27,487-28,323 \\
(278)\end{array}$ \\
\hline 14,300 & $\begin{array}{c}366-20,362 \\
(6665)^{*}\end{array}$ & $\begin{array}{c}20,359-24,408 \\
(1349)\end{array}$ & $\begin{array}{c}24,405-25,079 \\
(224)\end{array}$ & $\begin{array}{c}25,051-25,296 \\
\text { (81) }\end{array}$ & $\begin{array}{c}25,307-25,984 \\
(225)\end{array}$ & $\begin{array}{c}26,002-27,159 \\
(385)\end{array}$ & $\begin{array}{c}27,162-27,998 \\
\text { (278) }\end{array}$ \\
\hline 15,073 & $\begin{array}{c}366-20,365 \\
(6666) *\end{array}$ & $\begin{array}{c}20,362-24,411 \\
(1349)\end{array}$ & $\begin{array}{c}24,408-25,082 \\
(224)\end{array}$ & $\begin{array}{c}25,054-25,299 \\
(81)\end{array}$ & $\begin{array}{c}25,310-25,987 \\
(225)\end{array}$ & $\begin{array}{c}26,005-27,165 \\
(386)\end{array}$ & $\begin{array}{c}27,168-28,004 \\
(278)\end{array}$ \\
\hline 15,593 & $\begin{array}{c}306-20,905 \\
(6866)\end{array}$ & $\begin{array}{c}20,902-24,933 \\
(1343)\end{array}$ & $\begin{array}{c}24,930-25,604 \\
(224)\end{array}$ & $\begin{array}{c}25,513-25,821 \\
(102)\end{array}$ & $\begin{array}{c}25,832-26,509 \\
(225)\end{array}$ & $\begin{array}{c}26,527-27,687 \\
(386)\end{array}$ & $\begin{array}{c}27,690-28,526 \\
(278)\end{array}$ \\
\hline
\end{tabular}

Post-translational cleavage of the replicase polyproteins into the complement of nonstructural proteins was predicted by zCurve for the six EbCoV genomes (Supplementary Table S1) [26]. The cleavage sites for the non-structural proteins are shown in Supplementary Table S2 [26].

\subsection{EbCoV Proteins Are Most Similar to Bat and Porcine Alphacoronaviruses}

BLASTP analysis of EbCoV, using strain 14300 as a representative sequence, was performed to identify the closest homologs apart from HCQD-2020. The ORF1ab protein was most similar to bat alpha-CoVs identified in Asia and Europe, as well the porcine severe acute diarrhea syndrome coronavirus (SADS-CoV) and PEDV, all with approximately $60 \%$ identity. The $S$ protein was most similar (47\% identity) to NL63-related and 229E-related bat CoVs and PEDV. ORF3 had approximately $40 \%$ identity to homologs found in bat alpha-CoVs. The envelope (E) protein was 50\% identical to bat and human alpha-CoVs. The membrane $(\mathrm{M})$ protein was $65 \%$ identical to those found in bat and swine alpha-CoVs. 
The nucleocapsid $(\mathrm{N})$ protein shared $79 \%$ identity to $\mathrm{N}$ from a partial sequence derived from the alpha-CoV E. fuscus Appalachian Ridge P1C837 and less than 50\% similarity to other bat alpha-CoVs. For both nucleotide and amino acid sequences of the ORF7 gene, no significant similarities were found by BLASTN and BLASTP, respectively, apart from 97.1\% identity to HCQD-2020.

\subsection{Eptesicus Bat Coronavirus Is Most Closely Related to Bat CoV HKU2}

Phylogenetic trees were constructed using the genome nucleotide sequences for $\mathrm{EbCoV}$ and representative alpha-CoV (Figure 3). Eptesicus bat $\mathrm{CoV}$ formed a well-supported, monophyletic clade along with HCQD-2020 and Rocky Mountain bat CoV 65 (RMCoV65). The high, greater than $96 \%$, nucleotide identity in the conserved replicase-encoding regions of the genome, along with close evolutionary histories, suggests that EbCoV, HCQD-2020, and RMCoV65 are members of the same species, EbCoV. The EbCoV clade was most closely related to a clade comprised of bat CoV HKU2 and SADS-CoV that occupied a well-supported sister clade position in the tree.

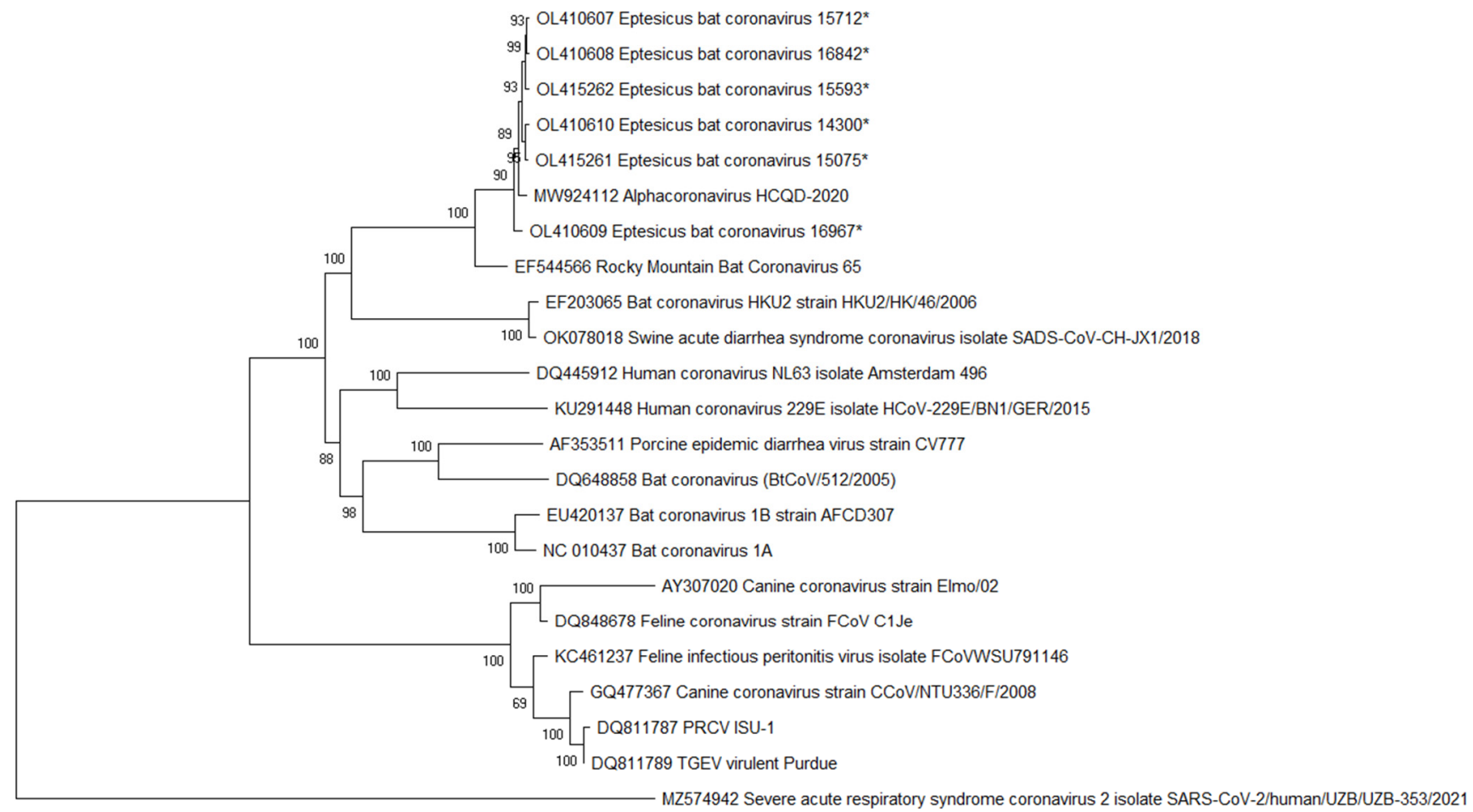

Figure 3. Phylogenetic analysis of complete genome sequences was performed in MegaX using the maximum likelihood method along with a GTR + G substitution model [21,22]. The bootstrap values were calculated from 500 replicates, and values greater than 70 are shown. Sequences determined here are indicated by *.

Phylogenetic analysis was performed on the ORF1ab gene derived from the nearcomplete genome sequences and partial RdRp sequences determined here. All strains formed a monophyletic clade that included RMCoV65 with strong bootstrap support. These results suggest that all $12 \mathrm{CoV}$-positive strains identified here are conspecific (Figure 4). Bat CoV strain HKU2 and SADS-CoV2 occupied a sister clade position to the EbCoV clade. 


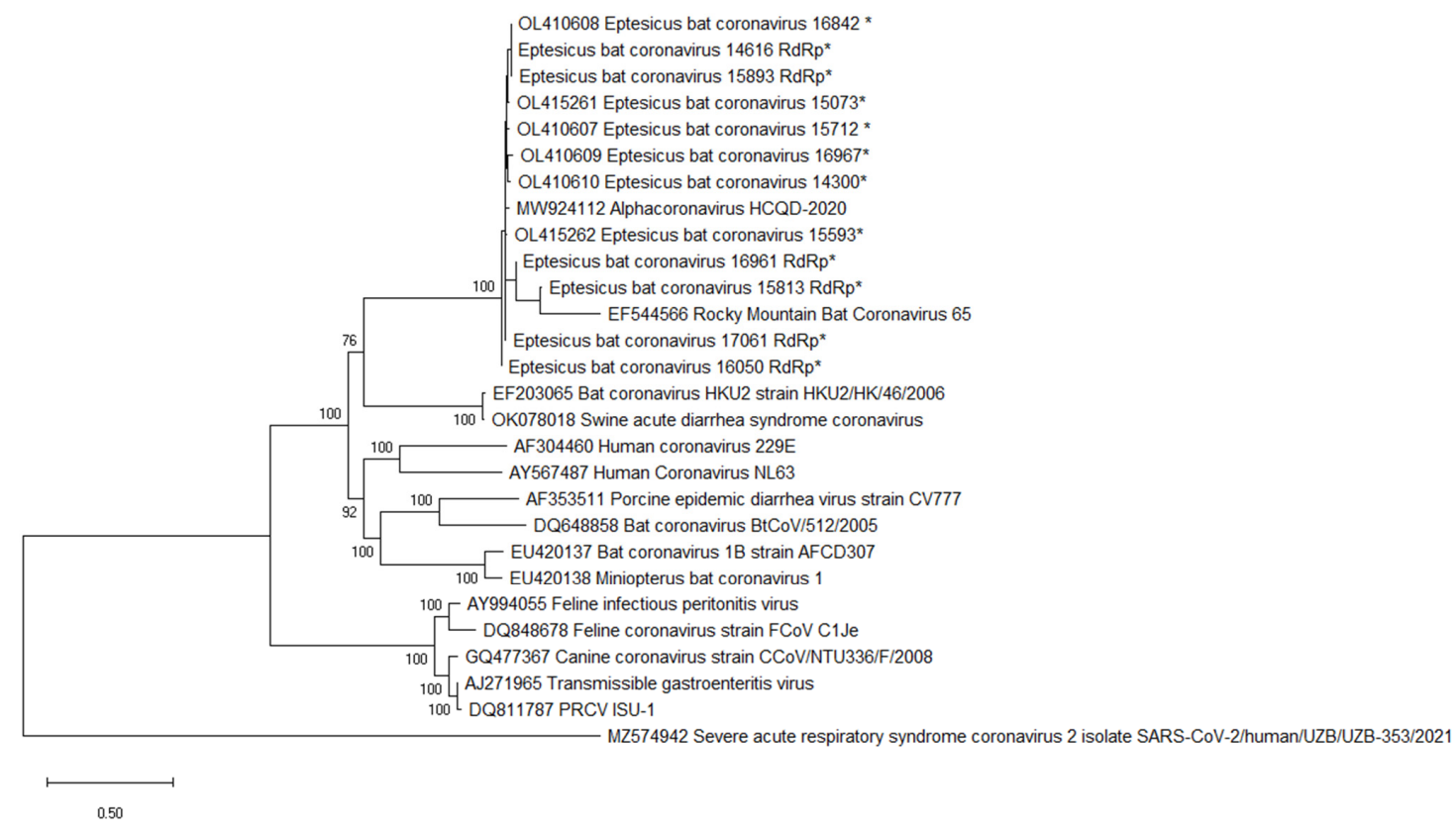

Figure 4. Phylogenetic analysis of ORF1ab nucleotide sequences was performed in MegaX using the maximum likelihood method along with a GTR + G substitution model [21,22]. The bootstrap values were calculated from 500 replicates, and values greater than 70 are shown. EbCoV sequences with the RdRp suffix are partial sequences derived from the nested PCR amplicon. Sequences determined here are indicated by *.

Analysis of the $S$ gene sequences likewise found a close evolutionary relationship between EbCoV strains from the U.S. and Korea that again formed a well-supported monophyletic lineage (Figure 5). A clade comprised of bat CoV strain 512 (BtCoV/512/2005) and PEDV formed a sister clade to the EbCoV with moderate bootstrap support. Interestingly, the EbCoV S gene sequences showed closer evolutionary relationships to swine and companion animals CoVs than the bat CoV HKU2 as seen for phylogenetic analysis of full genome sequences.

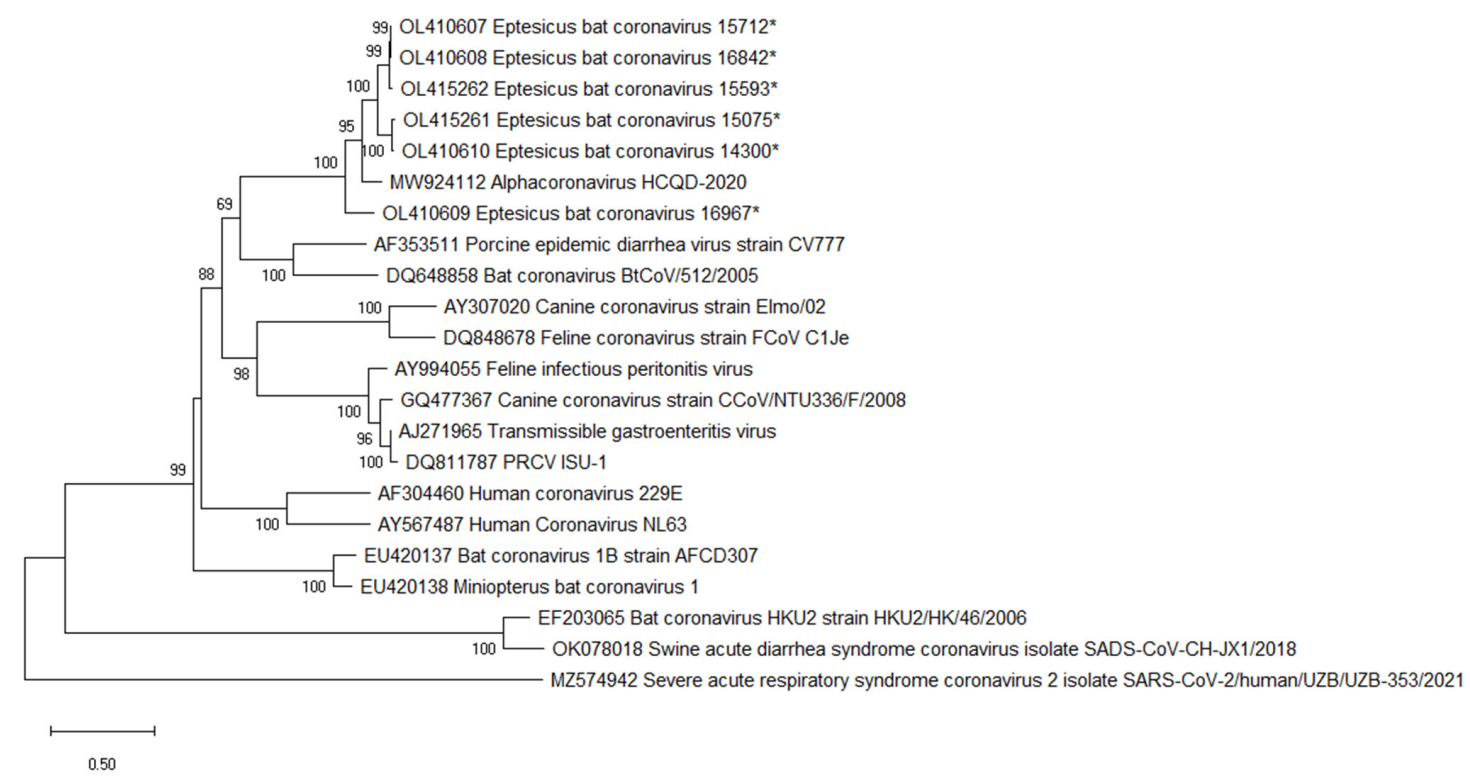

Figure 5. Spike gene sequence phylogenetic tree inferred by MegaX using maximum likelihood methodology and the GTR + G substitution model [21,22]. The bootstrap values are from 1000 replicates. Bootstrap values greater than 68 are shown. Sequences determined here are indicated by * 
Phylogenetic analysis of the remaining genes found that all EbCoV strains formed a single, monophyletic clade (Supplementary Figures S2-S5). Tree topologies, however, lacked strong statistical support.

\subsection{Recombination Analysis}

Recombination analysis was performed for $\mathrm{EbCoV}$ and reference sequences for PEDV, HCoV-NL63, HCoV-229E, HKU2, Bat CoV strain 1A, CCoV, FIPV, and TGEV. No statistically significant $(p<0.05)$ recombination events were identified.

\subsection{Virus Isolation}

Attempts to isolate viruses from CoV-positive samples were unsuccessful on Vero76 and Efk3 cells. No cytopathic effects were evident, and all cell culture supernatants were negative for $\mathrm{CoV}$ by pan-CoV PCR following two passages.

\section{Discussion}

In this study, novel alpha-CoVs from Eptesicus fuscus in SD and Minnesota were characterized. The sequences of six genomes and six RdRp domains were determined directly from bats. The sequences were highly similar to an RdRp sequence previously determined from E. fuscus in the U.S., RMCoV65, which was proposed as a new species of alphaCoV, EbCoV. These sequences were additionally highly similar to a bat alpha-CoV identified from E. serotinus in South Korea while this manuscript was being prepared. Genetic and phylogenetic analyses demonstrated a close relationship between U.S. and Korean sequences for all genes. The high similarity between the E. fuscus derived CoV sequences here, the Korean CoV HCQD-2020 derived from E. serotinus, and the partial sequences previously recovered from E. fuscus in the U.S. suggests a single Eptesicus alpha$\mathrm{CoV}$ species, EbCoV. Interestingly, E. fuscus and E. serotinus are closely related and may be conspecific [27].

EbCoV was identified in 12 of 174 (6.9\%) of bats included in our study. These results demonstrate that EbCoV is common in E. fuscus. Importantly, the bats included in our study were all submitted for rabies virus testing due to human exposure. E. fuscus is common through the U.S. and is the dominant bat species in the upper Midwest. The insectivorous $E$. fuscus is synanthropic and frequently roosts in human-made structures, leading to frequent interaction with humans. Besides being a known reservoir for the rabies virus, E. fuscus harbors many viruses that may pose zoonotic risks [28-32].

In 2017, a severe outbreak of the enteric disease occurred in Chinese pig farms. A novel $\mathrm{CoV}$, swine enteric alphacoronavirus, was isolated from diseased pigs. This virus, later renamed SADS-CoV, was found to be closely related to bat CoV HKU2 identified in Rhinolophus bats [33,34]. Phylogenetic analysis of EbCoV genome sequences here identified a close evolutionary relationship to SADS-CoV and HKU2 with strong bootstrap support. In addition, BLASTP analyses of EbCoV S proteins found PEDV S proteins were amongst the most similar known $\mathrm{CoV}$ proteins. Analysis of evolutionary signatures from EbCoV from a Korean bat found that animals in the order Artiodactyla were as likely to be infected with $\mathrm{EbCoV}$ as bats in the family Vespertilionidae, which include Eptesicus [25,35]. Together, these results suggest pigs may be susceptible to spillover from EbCoV.

To date, three alphaCoVs have been shown to infect pigs. Similar to SADS-CoV in China, the introduction of PEDV to the U.S. in 2013 led to an epidemic of severe disease [36]. While U.S. PEDV sequences were highly similar to contemporaneous Chinese PEDV, phylogenetic analyses support an evolutionary bat origin for PEDV.

Phylogenetic analysis of full CoV genome sequences found a well-supported sister clade relationship between $\mathrm{HKU} 2$ and EbCoV. Topological incongruences were evident, however, for single-gene phylogenies. For the spike gene, EbCoV was most closely related to a clade containing PEDV and only distantly related to HKU2. Despite this, recombination analysis failed to identify evidence of recombination. We hypothesize that the dearth of $\mathrm{CoV}$ sequences originating from wildlife in North America has prevented the characterization 
of close relatives to $\mathrm{EbCoV}$ that would allow for a better understanding of its evolutionary history.

Compared to elsewhere in the world, comparably little surveillance for bat CoVs have been performed in the Americas. The vast majority, $89 \%$, of New World CoVs are alpha-CoVs, which includes all CoVs identified in Eptesicus [17]. Here we identified 12 $\mathrm{CoV}$-positive E. fuscus using pan-CoV primers, all of which were EbCoV, suggesting little $\mathrm{CoV}$ diversity in E.fuscus in the upper Midwest. Experimental inoculation of E. fuscus with SARS-CoV-2 also found no evidence of infection [37]. As our study utilized samples collected from limited geography, further surveillance is needed to assess the breadth of CoV diversity in U.S. bats.

Supplementary Materials: The following are available online at https:/ /www.mdpi.com/article/10 .3390/v14020184/s1, Figure S1: Map of South Dakota counties showing distribution of bat samples included in this study. Color-coded counties represent number of bat samples; Figure S2: Phylogenetic analysis of the ORF3 gene sequences; Figure S3: Phylogenetic analysis of the envelope gene sequences; Figure S4: Phylogenetic analysis of the membrane gene sequences; Figure S5: Phylogenetic analysis of nucleocapsid gene sequences; Table S1: Predicted sizes for Eptesicus bat CoV non-structural proteins derived from polyprotein ORF1ab. * , incomplete sequence; Table S2: Predicted cleavage sites for the non-structural proteins (nsp) of Eptesicus bat coronavirus.

Author Contributions: R.S. and B.M.H. designed and conceptualized the experiments; R.S. and G.T. performed the experiments; R.S., G.T. and B.M.H. analyzed the data; R.S. prepared the original draft; G.T and B.M.H. reviewed and edited the paper. All authors have read and agreed to the published version of the manuscript.

Funding: This research was funded by the National Institutes of Allergy and Infectious Diseases, grant number 1R21AI162594-01.

Institutional Review Board Statement: Ethical review and approval for this study was waived due to bat samples were submitted to the South Dakota State University Animal Disease Research and Diagnostic Laboratory (SDSU ADRDL) for rabies testing due to human exposure, and as such, no specific approval was required. All tissue processing, RNA extraction, and viral isolation of the bat samples was performed in the SDSU ADRDL BSL-3 laboratory.

Data Availability Statement: The six complete bat CoV genomes were deposited into GenBank, according to the following accession numbers OL410607-OL410610, OL415261, and OL415262.

Acknowledgments: We would like to thank Martha Ohnstad and Craig Long for their assistance in securing samples, sequencing, and preparation.

Conflicts of Interest: The authors declare no conflict of interest.

\section{References}

1. Walker, P.J.; Siddell, S.G.; Lefkowitz, E.J.; Mushegian, A.R.; Adriaenssens, E.M.; Dempsey, D.M.; Dutilh, B.E.; Harrach, B.; Harrison, R.L.; Hendrickson, R.C.; et al. Changes to virus taxonomy and the Statutes ratified by the International Committee on Taxonomy of Viruses (2020). Arch. Virol. 2020, 165, 2737-2748. [CrossRef] [PubMed]

2. Lim, Y.X.; Ng, Y.L.; Tam, J.P.; Liu, D.X. Human Coronaviruses: A Review of Virus-Host Interactions. Diseases 2016, 4, 26. [CrossRef] [PubMed]

3. Fehr, A.R.; Perlman, S. Coronaviruses: An overview of their replication and pathogenesis. Methods Mol. Bio. 2016, 1282, 1-23.

4. Woo, P.C.; Lau, S.K.; Lam, C.S.; Lau, C.C.; Tsang, A.K.; Lau, J.H.; Bai, R.; Teng, J.L.; Tsang, C.C.; Wang, M.; et al. Discovery of seven novel Mammalian and avian coronaviruses in the genus deltacoronavirus supports bat coronaviruses as the gene source of alphacoronavirus and betacoronavirus and avian coronaviruses as the gene source of gammacoronavirus and deltacoronavirus. $J$ Virol. 2012, 86, 3995-4008. [PubMed]

5. Van der Hoek, L.; Pyrc, K.; Berkhout, B. Human coronavirus NL63, a new respiratory virus. FEMS Microbiol Rev. 2006, 30, 760-773. [CrossRef]

6. Li, F. Structure, Function, and Evolution of Coronavirus Spike Proteins. Annu. Rev. Virol. 2016, 3, 237-261. [CrossRef] [PubMed]

7. Van der Hoek, L. Human coronaviruses: What do they cause? Antivir. Ther. 2007, 12, 651-658.

8. Woo, P.C.; Lau, S.K.; Yip, C.C.; Huang, Y.; Yuen, K.Y. More and More Coronaviruses: Human Coronavirus HKU1. Viruses 2009, 1, 57-71. [CrossRef]

9. Schoeman, D.; Fielding, B.C. Human Coronaviruses: Counteracting the Damage by Storm. Viruses 2007, 13, 1457. [CrossRef] 
10. Cui, J.; Li, F.; Shi, Z.L. Origin and evolution of pathogenic coronaviruses. Nat. Rev. Microbiol. 2019, 17, 181-192. [CrossRef] [PubMed]

11. Pillaiyar, T.; Meenakshisundaram, S.; Manickam, M. Recent discovery and development of inhibitors targeting coronaviruses. Drug Discov. Today 2020, 25, 668-688. [CrossRef]

12. Zaki, A.M.; van Boheemen, S.; Bestebroer, T.M.; Osterhaus, A.D.; Fouchier, R.A. Isolation of a novel coronavirus from a man with pneumonia in Saudi Arabia. N. Engl. J. Med. 2012, 367, 1814-1820. [CrossRef] [PubMed]

13. $\mathrm{Hu}, \mathrm{B} . ; \mathrm{Ge}, \mathrm{X} . ;$ Wang, L.F.; Shi, Z. Bat origin of human coronaviruses. Virol. J. 2015, 12, 221. [CrossRef] [PubMed]

14. Leitner, T.; Kumar, S. Where Did SARS-CoV-2 Come From? Mol. Biol. Evol. 2020, 37, 2463-2464. [CrossRef]

15. Dominguez, S.R.; O'Shea, T.J.; Oko, L.M.; Holmes, K.V. Detection of group 1 coronaviruses in bats in North America. Emerg. Infect. Dis. 2007, 13, 1295-1300. [CrossRef] [PubMed]

16. Donaldson, E.F.; Haskew, A.N.; Gates, J.E.; Huynh, J.; Moore, C.J.; Frieman, M.B. Metagenomic analysis of the viromes of three North American bat species: Viral diversity among different bat species that share a common habitat. J. Virol. 2010, 84, 13004-13018. [CrossRef]

17. Hernandez-Aguilar, I.; Lorenzo, C.; Santos-Moreno, A.; Naranjo, E.; Navarrete-Gutierrez, D. Coronaviruses in bats: A review for the Americans. Viruses 2021, 13, 1226. [CrossRef]

18. Hu, H.; Jung, K.; Wang, Q.; Saif, L.J.; Vlasova, A.N. Development of a one-step RT-PCR assay for detection of pancoronaviruses $\left(\alpha-, \beta-, \gamma_{-}\right.$, and $\delta$-coronaviruses) using newly designed degenerate primers for porcine and avian 'fecal samples. J. Viro. Met. 2018, 256, 116-122. [CrossRef]

19. Holbrook, M.G.; Anthony, S.J.; Navarrete-Macias, I.; Bestebroer, T.; Munster, V.J.; van Doremalen, N. Updated and Validated PanCoronavirus PCR Assay to Detect All Coronavirus Genera. Viruses 2021, 13, 599.

20. Djikeng, A.; Halpin, R.; Kuzmickas, R.; De Passe, J.; Feldblyum, J.; Sengamalay, N.; Afonso, C.; Zhang, X.; Anderson, N.G.; Ghedin, E.; et al. 2008. Viral genome sequencing by random priming methods. BMC Genom. 2008, 9, 5. [CrossRef] [PubMed]

21. Nei, M.; Kumar, S. Molecular Evolution and Phylogenetics; Oxford University Press: New York, NY, USA, 2000.

22. Kumar, S.; Stecher, G.; Li, M.; Knyaz, C.; Tamura, K. MEGA X: Molecular Evolutionary Genetics Analysis across computing platforms. Mol. Biol. Evol. 2018, 35, 1547-1549. [CrossRef] [PubMed]

23. Lole, K.S.; Bollinger, R.C.; Paranjape, R.S.; Gadkari, D.; Kulkarni, S.S.; Novak, N.G.; Ingersoll, R.; Sheppard, H.W.; Ray, S.C. Full-length human immunodeficiency virus type 1 genomes from subtype C-infected seroconverters in India, with evidence of intersubtype recombination. J. Virol. 1999, 73, 152-160. [CrossRef] [PubMed]

24. Martin, D.P.; Murrell, B.; Golden, M.; Khoosal, A.; Muhire, B. RDP4: Detection and analysis of recombination patterns in virus genomes. Virus Evol. 2015, 1, 3. [CrossRef] [PubMed]

25. Do, H.Q.; Nguyen, V.G.; Chung, C.U.; Jeon, Y.S.; Shin, S.; Jang, K.C.; Pham, L.B.H.; Kong, A.; Kim, C.U.; Park, Y.H.; et al. Genomic characterization of a novel alphacoronavirus isolated from bats, Korea, 2020. Viruses 2021, 13, 2041. [CrossRef]

26. Chen, L.L.; Ou, H.Y.; Zhang, R.; Zhang, C.T. ZCURVE_CoV: A new system to recognize protein coding genes in coronavirus genomes, and its applications in analyzing SARS-CoV genomes. Biochem. Biophys. Res. Commun. 2003, 307, 382-388. [CrossRef]

27. Koopman, K.F. Order Chiroptera. In Mammal Species of the World; Wilson, D.E., Reeder, D.M., Eds.; Smithsonian Institute Press: Washington, DC, USA, 1993; pp. 137-241.

28. Hause, B.M.; Nelson, E.; Henning, C. Eptesicus fuscus orthorubulavirus, a close relative of human parainfluenza virus 4 , discovered in a bat in South Dakota. Microbiol. Spectr. 2021, 9, e0093021. [CrossRef] [PubMed]

29. Hause, B.M.; Nelson, E.; Christopher-Hennings, J. Novel and diverse non-rabies Rhabdoviruses identified in bats with human exposure, South Dakota, USA. Viruses 2020, 12, 1408. [CrossRef]

30. Subudhi, S.; Rapin, N.; Dorville, N.; Hill, J.E.; Town, J.; Willis, C.K.R.; Bollinger, T.K.; Misra, V. Isolation, characterization and prevalence of a novel gammaherpesvirus in Eptesicus fuscus, the North American big brown bat. Virology 2018, 516, 227-238. [CrossRef] [PubMed]

31. Emerson, G.L.; Nordhausen, R.; Garner, M.M.; Huckabee, J.R.; Johnson, S.; Wohrle, R.D.; Davidson, W.B.; Wilkins, K.; Li, Y.; Doty, J.B.; et al. Novel poxvirus in big brown bats, northwestern United States. Emerg. Infect. Dis. 2013, 19, 1002-1004. [CrossRef] [PubMed]

32. George, D.B.; Webb, C.T.; Farnsworth, M.L.; O'Shea, T.J.; Bowen, R.A.; Smith, D.L.; Stanley, T.R.; Ellison, L.E.; Rupprecht, C.E. Host and viral ecology determine bat rabies seasonality and maintenance. Proc. Natl. Acad. Sci. USA 2011, 108, 10208-10213. [CrossRef] [PubMed]

33. Zhou, P.; Fan, H.; Lan, T.; Yang, X.L.; Shi, W.F.; Zhang, W.; Zhu, Y.; Zhang, Y.W.; Xie, Q.M.; Mani, S.; et al. Fatal swine acute diarrhoea syndrome caused by an HKU2-related coronavirus of bat origin. Nature 2018, 556, 255-258. [CrossRef]

34. Yang, Y.L.; Qin, P.; Wang, B.; Liu, Y.; Xu, G.H.; Peng, L.; Zhou, J.; Zhu, S.J.; Huang, Y.W. Broad Cross-Species Infection of Cultured Cells by Bat HKU2-Related Swine Acute Diarrhea Syndrome Coronavirus and Identification of Its Replication in Murine Dendritic Cells In Vivo Highlight Its Potential for Diverse Interspecies Transmission. J. Virol. 2019, 93, 1448-1469. [CrossRef] [PubMed]

35. Babayan, S.A.; Orton, R.J.; Streicker, D.G. Predicting reservoir hosts and arthropod vectors from evolutionary signatures in RNA virus genomes. Science 2018, 362, 577-580. [CrossRef] 
36. Huang, Y.W.; Dickerman, A.W.; Pineyro, P.; Li, L.; Fang, L.; Kiehne, R.; Opriessnig, T.; Meng, X.J. Origin, evolution and genotyping of emergent porcine epidemic diarrhea virus strains in the United States. MBio 2013, 4, e00737-e007413. [CrossRef] [PubMed]

37. Hall, J.S.; Knowles, S.; Nashold, S.W.; Ip, H.S.; Leon, A.E.; Rocke, T.; Keller, S.; Carossino, M.; Balasuriya, U.; Hofmeister, E. Experimental challenge of a North American bat species, big brown bat (Eptesicus fuscus), with SARS-CoV-2. Transboud. Emerg. Dis. 2021, 68, 3443-3452. [CrossRef] [PubMed] 